\title{
Könyvismertetö \\ Székely Levente: Szürke hattyúk. Enigma 2001 Kiadó, Budapest, 2020
}

DOI: 10.15170/MM.2020.54.02.08

A ma élő generációk közül csak a legidősebbek éltek át ahhoz hasonló időket, amit a koronavírus okozta járványveszély miatt 2020 január végétől - változó kezdettel - 2,5-3 hónapon keresztül a világ szinte minden országa átélt vagy még éppen átél. Ez a váratlannak tűnő, ámde rendkívüli hatású jelenség pillanatnyi tapasztalataink és a kérdéssel foglalkozó kutatók szerint már mély nyomokat hagyott és hagy majd életünk szinte minden területén, szokásainkon, gondolkodásunkon, kapcsolatainkon. Ez a váratlan és kivételes helyzet különösen izgalmas kontextust teremtett Székely Levente Szürke hattyúk címü, 2020 tavaszán megjelent könyvének, melyben a szerző - aki 2012 óta a hazai nagymintás ifjúságkutatás szakmai vezetője - az általa vezetett kutatássorozat 2016-os hullámának eredményei alapján azt mutatja be, hogy mit tudunk a magyarországi és a külhoni magyar fiatalokról (a 15-29 éves korosztályról), és várhatóan hogyan alakulnak majd ezek a jellemzők a jövőben.

Kezdjük a könyvismertetést magával a címmel. Miért éppen Szürke hattyúk? Kultúránkban a hattyúkhoz füződő szimbolikus jelentések közül talán a legismertebb a fehér hattyú - fekete hattyú ellentétpár. Számos műalkotásban szerepel a kiszámítható, tiszta, már-már negédesen tökéletes szépségű, kecses, fehér hattyú, illetve fekete ellentettje, a veszélyes, titokzatos, félelmetes erejủ démon. A fehér és a fekete hattyúk egy fontos dologban azonban nem különböznek: mindkettőnek szürkék a fiókái. Vagyis a fiatal (szürke) hattyúkról egy adott pillanatban még nem tudhatjuk, hogy felnőve fehérek vagy feketék lesznek-e.

A tudomány minden bizonnyal leghíresebb hattyú motívuma a Nassim Nicholas Taleb (2007) nevéhez füződő fekete hattyú jelenség, a rendkívül valószínütlen, kiszámíthatatlan, váratlan események hatásának elmélete. Ez a jelenség abból az általánosan jellemző gondolkodásból fakad, hogy az ember hajlamos meglévő tapasztalataiból, megfigyeléseiböl, ismereteiből igazságot konstruálni és eközben megfeledkezni arról, hogy lehetnek/vannak dolgok, amiket nem ismer, és amelyek megcáfolhatják az igazságnak gondolt állításokat. A hattyúkat pl. mindaddig fehér színünek tartották a tapasztalatok alapján, amíg Ausztrália felfedezésével ismertté nem vált az ott honos fekete változat is. A fekete hattyú így lett az addig igazságnak tartott dolgok cáfolatának szimbóluma, amelyet a váratlanság (az addigi tapasztalatoktól való nagyfokú eltérés) mellett az is jellemez, hogy tömeghatást vált ki (óriási horderejü következményekkel jár), valamint, hogy csak utólag magyarázható kevésbé valószínütlen, váratlan jellege.

Székely Levente könyve tehát nem véletlenül kapta a Szürke hattyúk címet. Az ismert társadalomkutató a kötet összefoglalójában ezt írja munkája céljáról és annak várható eredményéröl: „A Szürke hattyúkban megkíséreltem összefoglalni mindazt, ami a nagymintás ifjúságkutatásból következik, legyen az akár tartalmi, akár módszertani tanulság. Egy ilyen összefoglaló próbálkozás önreflexív munka is egyben, amelyben terítékre kerül mindaz, amit eddig az ifjúságkutatás kapcsán állítottam, de vajon mindezek segítségével végül sikerült-e választ adni arra kérdésre, hogy milyenek a fiatalok, és milyenek lesznek a jövőben?" (Székely 2020:192).

A fenti idézet jól érzékelteti, hogy a hattyú analógiát Székely Levente mind a fehér-fekete dichotómia, mind a fekete hattyú jelenség szempontjából relevánsnak tartja könyve kapcsán:

A mai fiatalokról (a szürke hattyúkról) a róluk szerzett ismeretek alapján most még nem igazán tudhatjuk, hogy szokásaik, életvitelük, nézeteik terén hoznak-e majd markáns változásokat a társadalom életébe, lesz-e belőlük új „,nagy generáció” vagy felnőve csendesen belesimulnak a fennálló struktúrákba.

Nem biztos, hogy elegendő, ha eddigi tudásunkból, kutatási eredményeinkből kiindulva válaszolunk arra a kérdésre, hogy milyenek a fiatalok, mert mindig jöhet egy újabb példa, amely ezt megcáfolja. Különösen jogos ez a bizonytalanság érzés, ha a rendelkezésre álló tapasztalatokból a jövőre vonatkozóan konstruálunk állításokat. Bár a könyv megírásakor a szerző még aligha gondolhatott a koronavírus okozta súlyos következményekre, a világjárvány, mint fekete hattyú mindennél jobb bizonyítéka ennek a kétkedésnek.

A Szürke hattyúk címú könyv öt nagy tartalmi fejezetből áll, melyből az első fejezet az ifjúkor folyamataival és a fiatal nemzedék kutatásokból megismert főbb jellemzőivel foglalkozik. Elöször is megállapítja, hogy az utóbbi évtizedekben alapvetóen megváltozott az ifjúsági életszakasz, amely régebben az élet kitün- 
tetett korszaka volt, mert minden, ami fontos, ekkor történt az emberekkel: megszerezték legmagasabb iskolai végzettségüket, majd megkezdték keresőtevékenységüket, elszakadtak orientációs családjuktól és saját családot alapítottak. Ezt a lineáris modellt váltotta fel egy pályamódosításokkal, szakmai profilbővítésekkel, lifelong learning-gel megtüzdelt, elhúzódó és széttöredezett tanulási folyamat. A család korábban jellemző stabil intézménye helyére is különböző új együttélési formák léptek, és általánosan elfogadott lett a válás. Székely két tényezőt lát az ifjúsági életszakasz jellemzőinek megváltozása hátterében: a kivárás taktikáját és az elköteleződés tudatos elutasítását, melyeket egyöntetủen a világ bizonytalanságára, a változékony viszonyokra adott válaszként értelmez. A magyar ifjúság esetében ez a bizonytalanság olyan rendszerszintủ változások következménye, mint a rendszerváltás, a globalizáció és az információs társadalom, melyek új struktúrákat eredményeztek a gazdasági, a társadalmi és a kulturális alrendszerekben. Ilyen új struktúra a gazdaságban a kapitalista modell, a globális betagozódás, az információalapú termelés és fogyasztás, a társadalomban az egyenlőtlenségek növekedése, a mobilitás felerősödése és a digitális megosztottság, a kulturális alrendszerben a demokratikus folyamatok kiépülése, a fogyasztói társadalom értékeinek megerösödése, a neoliberalizmus terjedése és a digitális kultúra megjelenése.

Az ezredforduló óta több hullámban végzett nagymintás ifjúságkutatások eredményei azt mutatják, hogy a rendszerváltás óta eltelt évtizedek értékelése a fiatalok körében összességében ugyan javuló tendenciát mutat, de alapvetően inkább negatív. A legtöbb vizsgálati szempont szerint jobbnak ítélik a Kádár-rendszert, és ezt elsősorban a kiszámíthatóság és az anyagi biztonság miatt még azok a fiatalok is így gondolják, akik életkoruk miatt erre nem emlékezhetnek. A rendszerváltás óta jóval nagyobb teret élvező demokratikus értékek és szabadságjogok korántsem kapnak ilyen jelentőséget az ifjúság gondolkodásában. Véleményük jól belesimul abba az elsősorban anyagi értékeket preferáló általános értékrendbe, amely a nemzetközi értékvizsgálatok szerint is jellemzi a magyar társadalmat (Inglehart-Welzel 2014).

Székely kiemeli, hogy a globalizáció hatásai Magyarországon leginkább a fogyasztásban (ugyanazon világmárkák, hasonló igények, média közvetítette globális sztenderdek), ezen belül is különösen a médiafogyasztásban mutatkoznak meg. Médiafogyasztásban a magyar ifjúság - a többi korosztállyal ellentétben - már egy évtizede együtt mozog a globális trendekkel: uralkodó médiuma az internet, amit sokkal fontosabbnak tart, mint az idősebbek, és szerepét is egyre többre értékeli. Megfigyelhető egy éles életkori töréspont is: az 1970-es évek végén születettek és a náluk fiatalabbak médiafogyasztása lényegesen különbözik az idősebb korosztályokétól. Ezzel magyarázható, hogy a hazai generációs besorolás alapját a médiafogyasztási adatok képezik. A nagymintás ifjúságkutatási adatok tehát rávilágítanak, hogy a fiatalok esetében a „szabadidő-társadalom” helyett ma már indokoltabb a „képernyő-társadalom” elnevezés.

A fejezet további részében áttekintésre kerülnek a fontosabb magyarországi vonatkozású ifjúságelméletek, köztük a szerző által jegyzett csendes generáció paradigma. A 2016-os nagymintás ifjúságkutatás adatait a 2012-es kutatással összevetve megállapítja, hogy a fiatalok továbbra is csendes attitüdü generációt alkotnak: jellemző rájuk a konformitás, a fennálló status quo és szüleik életeszményének elfogadása, a bizonytalanság érzése, az elkötelezettség hiánya, a céltalanság, ugyanakkor a rendezettség iránti vágy. Változatlanul passzív állampolgárok, apolitikusak, szabadidejüket zömmel otthon töltik a képernyők előtt és mozgásszegény életet élnek. A generációs megközelítéssel Székely megvédi a sok kritikát kiváltó generációs elméleteket, hiszen a generációs besorolás logikája szerint arra a fontos kérdésre keressük a választ, hogy milyenek a mai fiatalok, akik majd a jövőben a világot alakítják.

Kutatástörténeti és módszertani szempontból értékes a könyv második fejezete, amely magát az ifjúságkutatást mutatja be. Kitér a nagymintás kutatás történetére, vizsgálja a kutatás tematikus felépítését, a kutatási témák súlyát és ezek változásait, részletesen bemutatja a 2016-os kutatás tematikáját, valamint a mintatervezés és az adatfelvétel folyamatát. Utóbbiak azért is fontos kérdések, mert a kutatássorozat a magyarországi fiatalok mellett a külhoni magyar fiatalokra is kiterjed.

Izgalmas rész a könyv harmadik fejezete, amely a kutatások korábbi elemzéseiből kimaradt kérdéseket tárgyalja. A fiatal generáció életét, gondolkodását két évtizede vizsgáló nagymintás kutatássorozat széles tematikát ölel fel. Mivel a négyéves ciklusokban végzett adatfelvétel természetesen valamelyest mindig változó, aktualizált kérdőívek alapján zajlik, az összehasonlíthatóság és a tendenciák kirajzolása érdekében az adatok feldolgozása a legfontosabbnak ítélt kérdések mentén, kötött tartalommal történik. Következésképpen a kutatási gyorsjelentések az olyan alapkérdésekre terjednek ki, mint a demográfiai, az oktatási, a munkaerőpiaci folyamatok, a fogyasztás, a jövőterv, a politikai érdeklődés stb. (ld. pl. Székely-Szabó 2016), a későbbi feldolgozások pedig általában egy-egy témakörre koncentrálnak. Székely ezért tartja aktuálisnak, hogy azok az adatok is feldolgozásra kerüljenek, amelyeket a kutatócsoport a tervezésnél fontosnak tartott, de eddig még nem kerültek publikálásra. Ez a törekvés nemcsak teljesebbé teszi 
a kutatási eredmények bemutatását, de jól hasznositható a következő kutatási hullám előkészítésében is. A 2016-os kutatásból elöször ebben a fejezetben kerül bemutatásra pl. az, hogy a fiatalok mit hoznak az orientációs családjukból, milyen háttérrel lesznek anyagilag függetlenek, hogyan mélyülnek el a digitális kultúrában, miként integrálódnak a társadalom szövetébe, miként mutatnak fel nemzedéki jelleget vagy simulnak a meglévő struktúrába (Székely 2020: 113). Emeljünk ki két példát az új elemzések köréből! Korábban nem vizsgálták részletesen pl. a gyermekvállalást befolyásoló attitüdöket. Itt most kiderült, hogy a gyermekkel még nem rendelkező fiatal megkérdezettek ötöde nem tud érdemben arra válaszolni, hogy mikorra tervezi első gyermeke megszületését. Az érdemben válaszolók által említett átlagos életkor 29 év, és ebben nincs szignifikáns különbség a nemek és a korcsoportok között. A gyermekvállalás kitolódását alapvetően anyagi, lakhatási okokkal magyarázzák, és meglehetősen általános az a vélemény, hogy a gyermekvállalást jobban kellene támogatni. A kutatócsoport fontosnak tartotta a jól meghatározható társadalmi csoportok közötti ellentétek, valamint a saját társadalmi szerepvállalási lehetőségek percepciójának vizsgálatát is a fiatalok körében. Az adatelemzésből az derül ki, hogy témától függően igen eltérően érzékelik a fiatalok a társadalmi feszültségeket. A válaszadók kétharmada a kormány-ellenzék feszültséget ítéli a legnagyobbnak Magyarországon, ami Székely (2020:135) szerint hozzájárulhat a fiatalok politikai paszszivitásához. Ettől alig marad el a gazdagok és szegények közötti különbség kedvezőtlen megitélése, bár ezt erőteljesen befolyásolja a szubjektív anyagi helyzet. Jelentős többség (61 \%) érzékeli negatívan a származáson alapuló különbségeket is (bevándorlók és itt születettek; cigányok és nem cigányok). A fiatalok a legkisebb feszültséget a gyermekes és gyermektelen családok, ezt követően a szülök és gyermekeik között látják. Utóbbit Székely (2020:135) a csendes generáció-hipotézis megerősítéseként értékeli. Nem tartják jelentősnek a megkérdezettek a nők és férfiak közötti ellentétet, de a fiatalok és idősek viszonyában már jobban megoszlanak a válaszok. A politikai passzivitás egy további magyarázata lehet az a percepció, ahogyan a fiatalok a társadalmi döntésekbe való bekapcsolódásuk lehetőségét látják. Tízböl közel hat válaszadó úgy érzi, hogy nincs lehetősége beleszólni az országos közügyekbe, helyi szinten ugyanez a véleménye minden második megkérdezettnek.

A könyv negyedik fejezete - hasonlóan az ifjúságkutatás módszertanával foglalkozó részhez -kicsit kilóg a sorból. Az ifjúsági tematika ugyan itt is megvan, de a fejezetben közölt megállapítások nem az előzőekben alkalmazott nagymintás ifjúságkutatási adatok elemzéséből származnak, hanem egy négy évet felölelő médiaelemzésből, amely az Observer Budapest Kft. adattárának felhasználásával történt. A szerző azzal a céllal választotta ezt a módszert, hogy a fiatalok jellemzését maguknak a fiataloknak a válaszain alapuló adatok mellett más nézőpontból is megvilágítsa, másfajta forrásokkal is kiegészítse, és ennek a külső képnek a megalkotásához a média megjelenítést találta leginkább alkalmasnak.

A retrospektív elemzések után a könyv utolsó fejezetében a jövő irányába fordul a szerző, és arra vállalkozik, hogy néhány, általa kulcsterületnek tartott kérdéskörre fókuszálva középtávú becslést adjon arról, hogy milyen lesz a jövő ifjúsága. Fontos megállapítása, hogy az elmúlt száz év alatt csaknem megduplázódott várható átlagos élettartam, a technológiai fejlődés miatt gyorsan változó munkaerőpiac és a digitális technika nyújtotta foglalkozási lehetőségek olyan új helyzetet teremtenek, amelyben egyre kevésbé lesz fontos tényező az életkor. Ezért pl. megváltozhat a fiatalság szó jelentése: kitolódhat az ifjúság életkori határa vagy a pályamódosítások miatt akár többször is lehetünk fiatalok.

Bár az ifjúsághoz természetes módon kötjük a lázadást, a szabályok elutasítását és újak kialakítását, a 2016-os ifjúságkutatás eredményei azt mutatják, hogy a magyarországi fiatalok elfogadják és betartják a társadalmi normákat és inkább pozitívan viszonyulnak az idősebb generációkhoz. Az elmúlt egy-két évtizedben csak néhány jelentős ifjúsági megmozdulás történt (pl. az internetadó elleni tüntetés, a Hallgatói Hálózat fellépései, a klímavészhelyzet elleni tüntetés). Székely úgy látja, hogy a mai fiatalok számára a digitális szcéna jelenti az ellenkultúrát, amit a sajátjuknak éreznek, ami kielégíti élmény iránti vágyukat, ahol közösségeket alkothatnak és ami ugyanakkor rejtve marad a szülők, a tanárok, a munkaadók elől.

A jövő társadalmát városias, technológiaintenzív környezetben képzeli el, amely társadalmi kooperáció nélkül működésképtelen. Ennek három fontos előfeltételét nevezi meg: egyik az információ és tudás, amely megsokszorozódik, és kezelésében a mesterséges intelligencia lesz az ember segítségére. A mesterséges intelligencia át fogja szőni a mai fiatalok életét, és a munkavégzés mellett a legszélesebb körben segíti majd a magánélet megszervezését is, így növelve a kényelmet, a jóllétet. A társadalmi kooperáció másik feltétele a bizalom átalakulása, amely az emberekről és az intézményekről áthelyeződik a technológiára (hiszen minden információt az interneten, a felhőben tárolunk). Ez pedig a hatalmi struktúra átalakulását eredményezi, ami a kooperáció harmadik feltétele. Jellemzője, hogy nem büntet, hanem lehetőséget ad és ösztönöz. Ennek jeleit már megtapasztalhatjuk, hiszen a mobiltechnológia révén pl. a munkavállaló bárhol 
és bármikor elérhető. A szerző ugyanakkor azt is hozzáteszi, hogy a közösségi megosztáson alapuló rendszerek elősegítik a korrekt, becsületes viselkedést, mert ez az egyedüli kifizetődő magatartás.

A könyvben leírtak összefoglalásaként Székely (2020:192-193) hangsúlyozza, hogy a 2016-os kutatási adatok alapján a 15-29 évesek nemzedéke a konform, bizonytalan, passzív attitűddel jellemezhető csendes generáció modellnek felel meg leginkább. (A modell természetesen leegyszerüsít és figyelmen kívül hagyja a csoport belső tagolódását, a szürke különböző árnyalatait.) A csendes generáció szocializációjára a rendszerváltás öröksége, a globalizáció és az információs társadalom gyakorolt jelentős hatást, leginkább a harmadlagos szocializációs közegben (média- és kultúrafogyasztás, kortárscsoport-kapcsolatok, digitális tevékenységek, sport, civil aktivitás), és formálta olyanná, amilyen. A generációs jellemzők mindenesetre jól megkülönböztetik ezt a csoportot a rendszerváltás előtti „táborok ifjúságától” és az ezredforduló „,fesztiválozós, plázázós" fiataljaitól. A jövőt illetően Székely azt tartja kulcskérdésnek, hogy képes lesz-e ez a generáció úgy használni az új technológiát, hogy közben uralja az információdömpinget, hogy fejleszti a társadalmi kooperációt és építi a bizalmat.

P.S.: És akkor a fekete hattyú jelenség. A koronavírus-járvány okozta vészhelyzetben az eddigieknél is jelentősebbé vált az internet és mindenféle digitális platformon végezhető tevékenység (oktatás, homeoffice, orvosi konzultáció stb.). Az iskolába járó fiatalok generációs élményévé vált a digitális oktatás. Ennek hatására már megfogalmazódtak olyan gondolatok, hogy a globális világjárvány alkalmas lehet egy új generáció - „vírus-generáció”, „karantinik” - definiálására (Szabó 2020). A fiatalok digitális kompetenciái is jelentősen felértékelődtek. „1968 után második alkalommal ismét a fiatalok kultúrája lett a mainstream.” (D. Kovács 2020). Ez akár új megvilágításba helyezheti a fiatal generáció jellemzését.

\section{HIVATKOZÁSOK}

D. Kovács, I. (2020): Átformálhatja a világot a karantinik generációja. 24.hu https://24.hu/kozelet/2020/03/28/koronavirus-digitalis-oktatas-fiatalok-karantinik-z-generacio/

Inglehart, R.-Welzel, Ch. (2014): Cultural map - WVS wave 6 (2010-2014). World Values Survey. http:// www.worldvaluessurvey.org/WVSContents.jsp

Szabó, A. (2020): A V, mint Vírus-generáció születése? PTI blog. https://politikatudomany.tk.mta.hu/ blog/2020/03/a-v-mint-virus-generacio-szuletese

Székely, L. (2020): Szürke hattyúk. Enigma 2001 Kiadó, Budapest

Székely, L.-Szabó, A. (2016): Magyar Ifjúság Kutatás 2016. Az ifjúságkutatás első eredményei. Ezek a mai fiatalok! Új Nemzedék Központ, Budapest

Taleb, N. N. (2007): The Black Swan. The Impact of the Highly Improbable. Random House, New York

Dr. Pavluska Valéria egyetemi docens

Pécsi Tudományegyetem 